\title{
De opbrengst van de politiële netwerkfunctie binnen de gebiedsgebonden politiezorg voor de kerntaken handhaving openbare orde en opsporing $^{*}$
}

\author{
Jelle Groenendaal \& Ira Helsloot
}

\begin{abstract}
De complexer wordende samenleving vraagt volgens beleidsmakers van de Nederlandse politie al jaren om een politieorganisatie die als netwerkspeler - of zelfs netwerkregisseur - opereert in zich steeds uitbreidende lokale veiligheidsnetwerken om de politiefuncties opsporing en handhaving openbare orde effectief te kunnen vervullen. Deze claim lijkt echter nog beperkt empirisch gevalideerd. Validatie is echter belangrijk omdat volgens onderzoek veel tijd wordt besteed aan de politiële netwerkfunctie binnen de gebiedsgebonden politiezorg en het de vraag is of die tijd $n u$ wel effectief wordt besteed. In dit artikel onderzoeken we daarom wat de opbrengst is van de politiële netwerkfunctie binnen de gebiedsgebonden politiezorg voor de kerntaken handhaving openbare orde en opsporing. Op basis van een beleidsanalyse, interviews en vijf weken participatief onderzoek binnen één politiekorps in Nederland constateren we dat het politiebeleid alleen wil 'nemen' uit en niet wil 'geven' aan lokale veiligheidsnetwerken, terwijl politiële netwerkers blijkens de praktijk en conform de netwerkliteratuur moeten geven om resultaten te kunnen boeken. Deze resultaten leverden gedurende ons participatief onderzoek overigens geen aantoonbare bijdrage aan de kerntaken van de politie, maar wél aan de leefbaarheid en sociale veiligheid in de buurt. Wij komen tot de slotsom dat wijkveiligheid gebaat is bij wijkagenten met een brede netwerkfunctie waarbij de illusie moet worden losgelaten dat dit leidt tot het kunnen wegzetten van niet-primair geachte politietaken.
\end{abstract}

\section{Introductie}

Sociologen stellen dat onze samenleving verandert; ze decentraliseert, desintegreert en verticale structuren veranderen in flexibele netwerken van kleine, verspreide eenheden: men spreekt van een netwerksamenleving (Castells, 2011). De netwerksamenleving heeft volgens politieonderzoekers ook gevolgen voor de politieorganisatie (Johnston \& Shearing, 2003; Wood \& Shearing, 2007). Onderzoekers die onderzoek hebben gedaan naar de gebiedsgebonden politiezorg constateren dat de lokale veiligheidszorg zich in toenemende mate organiseert in netwerken, dat wil zeggen een patroon van min of meer stabiele relaties van acto-

* Dit onderzoek is tot stand gekomen dankzij een subsidie van de onafhankelijke Commissie Politie en Wetenschap (CPW). CPW stimuleert wetenschappelijk en toegepast onderzoek op het terrein van de Nederlandse politiefunctie. 
ren die met elkaar afspraken maken over de aanpak van sociale overlast, onrust en criminaliteit in wijken (Johnston \& Shearing 2003; Wood \& Shearing 2007 Crawford 1997; Hughes \& Edwards 2002; Terpstra, 2010; Terpstra \& Kouwenhoven, 2004). Politieonderzoekers menen dat het ontstaan van lokale veiligheidsnetwerken vraagt om een 'netwerkende' politie, dat wil zeggen een politieorganisatie die intensief samenwerkt met burgers, publieke organisaties en private bedrijven om veiligheidsdoelstellingen te verwezenlijken. De rationale achter deze benadering is dat een succesvolle aanpak van deze problemen in een netwerksamenleving niet meer mogelijk is wanneer veiligheidsproblemen exclusief vanuit de politie worden benaderd (Shearing, 2005). Handhaving van de openbare orde en opsporing zijn in deze optiek niet (langer) het monopolie van de politie, maar een coproductie tussen verschillende partijen met gelijksoortige maar zeker ook verschillende belangen. Dit vergt van de politie mogelijk een andere rol dan ze normaliter gewend was: de 'agent 2.0' moet kunnen netwerken, regisseren, partijen bij elkaar brengen, eigen problemen 'integraal' benaderen, participeren in allerhande gremia en verantwoording afleggen aan meerdere partijen, zoals netwerkpartners, burgers, media en niet in de laatste plaats de eigen organisatie.

In het laatste decennium heeft de politiële netwerkfunctie binnen de gebiedsgebonden politiezorg een prominente positie gekregen binnen het politiebeleid. De Nationale Politie heeft de netwerkfunctie binnen de gebiedsgebonden politiezorg volledig omarmd. In het Inrichtingsplan van de Nationale Politie uit 2012 wordt beschreven dat wijkagenten 'een sleutelfunctie' binnen de politieorganisatie ('robuuste basisteams') vervullen en in netwerken moeten opereren om informatie te delen en ketenpartners te stimuleren om een bijdrage te leveren aan de lokale veiligheidszorg.

Een nog beperkt onderzochte vraag is wat het participeren in lokale veiligheidsnetwerken de politie in Nederland oplevert voor haar kerntaken handhaving van de openbare orde en opsporing. Deze vraag is relevant voor de praktijk, omdat onder meer uit onderzoek van Terpstra (2008b) blijkt dat wijkagenten een aanzienlijk deel van hun tijd besteden aan het participeren in lokale netwerken. Is dit wel een effectieve besteding van de schaarse politietijd? Meer specifiek staan drie vragen in dit artikel centraal. Ten eerste: welke doelstellingen heeft de politie met het participeren in lokale veiligheidsnetwerken? Ten tweede: hoe geven politiële netwerkers in de praktijk uitvoering aan de politiële netwerkfunctie? Ten derde: wat is de opbrengst van de politiële netwerkfunctie voor de kerntaken opsporing en handhaving openbare orde? Om deze vragen te beantwoorden hebben we zes weken lang kwalitatief onderzoek verricht binnen een Nederlands politiekorps. In de eerste plaats hebben we in kaart gebracht welke doelstellingen de Nederlandse politie heeft met het participeren in lokale veiligheidsnetwerken door het staande nationale politiebeleid te bestuderen. In de tweede plaats hebben we vijf wijkagenten van een politiekorps ieder één werkweek geobserveerd waarbij we in kaart hebben gebracht hoe zij uitvoering geven aan de politiële netwerkfunctie en wat dit concreet heeft opgeleverd voor de kerntaken opsporing en handhaving openbare orde. In de derde plaats hebben we interviews afgenomen 
met netwerkpartners, collega's en chefs van de wijkagenten om hun perceptie van de opbrengst van de politiële netwerkfunctie inzichtelijk te maken.

De bijdrage van ons onderzoek aan de huidige literatuur is tweeledig. In de eerste plaats is het huidige onderzoek naar de politie in relatie tot (lokale) veiligheidsnetwerken vaak beschouwend (bijvoorbeeld in termen van 'nodal governance' en 'anchored pluralism', zie Newburn, 2002; Dupont, 2004; Crawford et al., 2005; Hughes \& Rowe, 2007; Jones et al. 2009) en bovendien veelal normatief van aard (zie ook Van Steden, 2011, die ditzelfde punt maakt). Pogingen om de wijze waarop politiële netwerkers in de dagelijkse praktijk opereren gedetailleerd te beschrijven zijn nog zeldzaam. Ons onderzoek probeert in deze leemte te voorzien. In de tweede plaats proberen wij het bestaande onderzoek dat dit wel doet (zoals Johnston, 2005; Fleming \& Wood, 2006; Terpstra, 2010; 2008a; 2008b; Hamilton-Smith e.a., 2013) te falsificeren. In Nederland is al eerder empirisch onderzoek verricht naar de politiële netwerkfunctie (Terpstra, 2010; 2008a; 2008b; Terpstra \& Kouwenhoven, 2004). In het meest uitvoerige onderzoek beschrijft Terpstra (2008b) de mate waarin en wijze waarop wijkagenten invulling geven aan de verschillende aspecten van community policing, namelijk nabijheid (kennen en gekend worden door burgers), brede focus (een brede focus niet alleen op criminaliteit maar ook op gevoelens van sociale onveiligheid), preventie (nadruk op het voorkomen van onveiligheid), samenwerking met andere partijen (veiligheid beschouwen als co-creatie tussen publieke en maatschappelijke actoren) en betrokkenheid van burgers (betrekken van burgers bij het oplossen van veiligheidsproblemen). Ons onderzoek bouwt op dit onderzoek voort door enerzijds de resultaten uit dit onderzoek te falsificeren en anderzijds door meer gericht te onderzoeken wat het netwerken van politiële netwerkers nu precies inhoudt, zowel kwalitatief als kwantitatief. Door de politiële netwerkfunctie meer kwantitatief in beeld te brengen (bijvoorbeeld in termen van tijdsbesteding aan verschillende netwerkvormen), wordt het op den duur mogelijk om de netwerkpraktijken van verschillende politiekorpsen met elkaar te vergelijken. Hierdoor kan beter bepaald worden wat de netwerksamenleving nu concreet voor de politiefunctie en haar kerntaken betekent. Bovendien en tot slot trachten wij met ons onderzoek de internationale literatuur te verreiken door in kaart te brengen wat de politiële netwerkfunctie de politie nu precies oplevert voor haar kerntaken opsporing en handhaving openbare orde. Dit biedt input voor een geïnformeerde discussie over de ontwikkeling van lokale veiligheidsnetwerken en de rol van de politie daarbinnen.

Het vervolg van dit artikel is als volgt opgebouwd. In de volgende paragraaf gaan we in op de methoden van onderzoek. Vervolgens gaan we kort in op de netwerktheorie die we bestudeerd hebben als mede het huidige politiebeleid met betrekking tot de politiële netwerkfunctie. Daarna beschrijven we de resultaten van ons veldwerk. In de discussie die daarop volgt, plaatsen we de resultaten van ons onderzoek in een breder perspectief en komen we terug op de centrale onderzoeksvraag van dit artikel. In het besluit doen we tot slot aanbevelingen voor vervolgonderzoek en de politiepraktijk. 


\section{Methodologie}

Voor het beantwoorden van de drie onderzoeksvragen hebben we verschillende kwalitatieve onderzoeksmethoden gebruikt. Om een beeld van het staande politiebeleid te krijgen hebben we openbare beleidsdocumenten bestudeerd en aanvullend diepte-interviews gehouden met vier politiële beleidsmakers op strategisch niveau, twee politiële beleidsmakers op tactisch niveau en drie politieonderzoekers.

Om in beeld te krijgen hoe de politie in de praktijk uitvoering geeft aan de politiele netwerkfunctie hebben we de gebiedsgebonden politiezorg - die de basis vormt van de Nederlandse politie - als centrale casus genomen. Binnen de gebiedsgebonden politiezorg is de wijkagent volgens politiebeleid (Inrichtingsplan Nationale Politie 2012) en onderzoek (bijvoorbeeld Terpstra, 2008b) het kloppend hart voor (ook) de politiële netwerkfunctie. Om de (opbrengst van het) netwerken van de wijkagent in beeld te brengen hebben wij één weekdienst van vijf verschillende wijkagenten binnen een politiekorps geobserveerd. Een participatieve observatiemethode is een onderzoeksmethode die geregeld binnen politieonderzoek wordt toegepast en zeer geschikt is om te achterhalen wat professionals in hun natuurlijke omgeving doen, welke denkbeelden en ideeën daarachter steken, en met welke directe effecten (bijvoorbeeld Van Maanen, 1979). Het voordeel van participatieve onderzoeksmethode boven andere kwalitatieve onderzoeksmethoden zoals interviews is dat participatieve observatie minder gevoelig is voor sociaal wenselijke antwoorden en ideaalbeelden die professionals nog wel eens geneigd zijn te schetsen. Alvorens de observaties plaatsvonden, hebben we eerst diepte-interviews met de vijf wijkagenten gehouden om een eerste indruk te krijgen van de politiële netwerkfunctie in de praktijk. Enkele weken na de interviews vonden de observaties plaats. De in totaal 25 observatiedagen (5 per wijkagent) vonden plaats in juni, juli en augustus 2011 en zijn uitgevoerd door twee onderzoekers. Bij de keuze voor de vijf te observeren wijkagenten hebben we rekening gehouden met de mate van verstedelijking van het werkgebied (landelijk, half-stedelijk en stedelijk) van de wijkagent. We veronderstelden namelijk dat de mate waarin en wijze waarop wijkagenten opereren in netwerken beïnvloed wordt door het werkgebied waarin ze werkzaam zijn. De wijkagenten konden zich vrijwillig opgeven om mee te doen aan het onderzoek. Het onderwerp van het onderzoek is bij het werven van de wijkagenten niet vermeld, om selectie-effecten te beperken. In tabel 1 zijn de kenmerken van de wijk(en) van de geobserveerde wijkagenten weergegeven. 
Tabel 1: Kenmerken van de wijk per geobserveerde wijkagent

\begin{tabular}{|c|c|c|c|c|c|}
\hline & Wijkagent I & Wijkagent 2 & Wijkagent 3 & Wijkagent 4 & Wijkagent 5 \\
\hline $\begin{array}{l}\text { Werk- } \\
\text { gebied }\end{array}$ & $\begin{array}{l}\text { Stedelijk } \\
\text { gebied }\end{array}$ & $\begin{array}{l}\text { Stedelijk } \\
\text { gebied }\end{array}$ & Half-stedelijk & $\begin{array}{l}\text { Landelijk } \\
\text { gebied }\end{array}$ & Landelijk gebied \\
\hline $\begin{array}{l}\text { Omvang } \\
\text { wijk }\end{array}$ & $\begin{array}{l}4.000 \text { inwo- } \\
\text { ners }\end{array}$ & $\begin{array}{l}5.000 \text { inwo- } \\
\text { ners }\end{array}$ & $\begin{array}{l}10.000 \text { inwo- } \\
\text { ners }\end{array}$ & $\begin{array}{l}6.000 \text { inwo- } \\
\text { ners }\end{array}$ & 8.000 inwoners \\
\hline $\begin{array}{l}\text { Proble- } \\
\text { matiek } \\
\text { in de } \\
\text { wijk }\end{array}$ & $\begin{array}{l}\text { Drugshandel, } \\
\text { zwervers en } \\
\text { alcoholisten, } \\
\text { prostitutie, } \\
\text { jongeren }\end{array}$ & $\begin{array}{l}\text { Overlast in de } \\
\text { parken, zwer- } \\
\text { vers en alco- } \\
\text { holisten, jonge- } \\
\text { ren, parkeren }\end{array}$ & $\begin{array}{l}\text { Jongeren, } \\
\text { woonwagens }\end{array}$ & $\begin{array}{l}\text { Overlast op } \\
\text { recreatie- } \\
\text { park,buren- } \\
\text { ruzies }\end{array}$ & $\begin{array}{l}\text { Overlast jonge- } \\
\text { ren. Meer speci- } \\
\text { fiek: alcohol en } \\
\text { drugsgebruik } \\
\text { onder jongeren } \\
\text { (vooral in het } \\
\text { uitgaansgebied), }\end{array}$ \\
\hline
\end{tabular}

We hebben verschillende soorten diensten geobserveerd, waaronder 'reguliere' dag-, middag- en nachtdiensten, kermisdiensten, horecadiensten en noodhulpdiensten. Tijdens de 25 geobserveerde diensten hebben we alle werkzaamheden van de wijkagent mogen volgen. Bij het uitwerken van de observaties hebben we de nadruk gelegd op de gebeurtenissen die betrekking hebben op de politiële netwerkfunctie. Tijdens het observeren hebben we bijgehouden hoeveel tijd de wijkagenten besteden aan het participeren in de vier verschillende netwerken (geïnstitutionaliseerde en niet-geïnstitutionaliseerde netwerken, zowel formeel als informeel georganiseerd) als mede de een-op-een burgercontacten. Naast de participatieve observatie hebben we vijf beleidsmakers met een leidinggevende positie binnen de politie geïnterviewd. De observatieverslagen zijn openbaar en te downloaden op de website van de uitgever.

\section{Netwerkentheorie en het netwerkbeleid van de politie}

\subsection{De netwerktheorie}

In dit artikel definiëren wij een netwerk als 'a more or less stable pattern of social relations between interdependent actors, which take shape around policy problems and or policy programs' (Kickert e.a., 1997: 6). Onze focus ligt in dit artikel op lokale veiligheidsnetwerken, dus patronen van sociale relaties tussen wederzijds van elkaar afhankelijke actoren die zich bezig houden met lokale veiligheid en lokaal veiligheidsbeleid. Netwerken kunnen verschillende verschijningsvormen kennen. Het kan gaan om het horizontaal samenwerken binnen een bestuursniveau, maar ook om samenwerkingsverbanden die meerdere schaalniveaus omspannen (Hajer \& Wagenaar, 2003). Netwerken kunnen daarnaast uit verschillende soorten actoren bestaan. Er kan sprake zijn van een patroon van sociale relaties tussen de politie en geïnstitutionaliseerde actoren (waarbij onderscheid gemaakt kan worden tussen inter-organisatorisch zoals politie, gemeente en woningbouwcorporatie of intra-organisatorisch zoals verschillende afdelingen binnen de politieorganisatie) en tussen de politie en niet-geïnstitutionaliseerde actoren (politie en burgers). Bovendien kunnen netwerken op verschillende manieren georganiseerd zijn. Er kan sprake zijn van een netwerk met een formeel karakter (bijvoor- 
beeld planmatig georganiseerde overleggen tussen partijen aan de hand van een vergaderagenda en met verslaglegging al dan niet vastgelegd in convenanten of contractafspraken) of een meer informeel karakter (bijvoorbeeld een overleg dat spontaan ontstaat over lopende zaken in de wijk) (Provan \& Kenis, 2007). Opgemerkt moet worden dat wij het een-op-een contact tussen de politiële netwerker en individuele burgers niet onder een van deze vier netwerkvormen scharen. Tijdens de participatieve observaties hebben we de opbrengst van de een-op-een burgercontacten voor de kerntaken opsporing en handhaving openbare orde daarom in kaart gebracht als een afzonderlijke categorie.

Tabel 2: $\quad$ Vier archetypen netwerken

\begin{tabular}{lll}
\hline & Geïnstitutionaliseerde actoren & $\begin{array}{l}\text { Niet-geïnstitutionaliseerde acto- } \\
\text { ren }\end{array}$ \\
\hline Formeel & $\begin{array}{l}\text { Voorbeeld: Tweewekelijks overleg } \\
\text { tussen wijkagent en verschillende } \\
\text { ketenpartners zoals Bureau Jeugd- } \\
\text { zorg en woningcorporatie over spe- } \\
\text { cifiek thema met vergaderagenda en }\end{array}$ & $\begin{array}{l}\text { Voorbeeld: Maandelijks overleg van } \\
\text { wijkagent met bewonerscommissie in } \\
\text { het buurtcentrum met vergader- } \\
\text { verslaglegging }\end{array}$ \\
& $\begin{array}{ll}\text { Voorbeeld: Spontaan overleg tussen } \\
\text { wijkagent, jeugdzorgmedewerker en } \\
\text { medewerker van woningcorporatie }\end{array}$ & $\begin{array}{l}\text { Voorbeeld: Spontaan overleg tussen } \\
\text { wijkagent en bewonerscommissie }\end{array}$ \\
& $\begin{array}{l}\text { zonder vergaderagenda en verslagleg- } \\
\text { zonder vergaderagenda en verslagleg- }\end{array}$ \\
& ging & \\
\hline
\end{tabular}

De netwerktheorie gaat uit van horizontale relaties tussen de actoren in het netwerk. In een netwerk is geen enkele partij de baas. Netwerken worden gekarakteriseerd door een continue interactie tussen actoren gericht op uitwisseling van middelen en onderhandeling over gemeenschappelijke doelen (Rhodes, 2007). Een elementair principe hierbij is reciprociteit: plichten zijn wederkerig (De Bruijn \& Ten Heuvelhof, 2008). Actor A is aan actor B iets verplicht, in de wetenschap dat actor B op een volgend moment iets verplicht is aan actor A. Samenwerken in een netwerk vraagt dus om 'geven en nemen'. Wanneer je alleen maar 'neemt' uit het netwerk en niet(s) 'geeft', heb je als netwerkpartner simpelweg geen toegevoegde waarde en zal je uiteindelijk uit het netwerk vallen (Agranoff \& McGuire, 1999). Thompson en Perry (2006:27) stellen in dit verband: 'In collaboration, individual partners often demonstrate a willingness to interact collaboratively only if other partners demonstrate the same willingness. This "I will if you will" mentality (tit-for-tat reciprocity) is based on the perceived degree of obligation, such that partners are willing to bear initial disproportional costs because they expect their partners will equalize the distribution of costs and benefits over time out of a sense of duty.' Een vraag die wij daarom meenemen bij het bestuderen van het functioneren van wijkagenten in lokale netwerken is hoe ze omgaan met het principe van wederkerigheid.

Een aanverwante maar meer algemene vraag is hoe wijkagenten zich in de verschillende netwerken gedragen. Welke rol spelen ze in het netwerk en houdt het 
soort rol verband met de opbrengst van het netwerken? Op basis van de netwerktheorie hebben we zes netwerkrollen onderscheiden: plant (een actor die geen actieve bijdrage levert aan het netwerk en enkel 'neemt'), intermediair (een actor die actoren in het netwerk verbindt met externe actoren), expert (een actor die actoren in het netwerk voorziet van zijn kennis en expertise), facilitator (een actor die andere actoren in het netwerk helpt bij het oplossen van problemen), initiator (een actor die een nieuwe casus in het netwerk brengt) en regisseur (een actor die taken verdeelt en het besluitvormingsproces in het netwerk stuurt). Volgens het principe van reciprociteit ligt het in de lijn der verwachting dat actoren die enkel en alleen als plant of initiator opereren - en daarmee weinig 'geven' aan het netwerk - niet als volwaardige netwerkspelers worden gezien en daardoor uiteindelijk uit het netwerk zullen vallen.

\subsection{Het netwerkbeleid van de Nederlandse politie}

De kiem voor de huidige visie op de politiële netwerkfunctie is gelegd in het beleidsrapport Politie in Ontwikkeling (PiO) uit 2005. In dit rapport staat beschreven dat de politie enerzijds wil bijdragen aan het voorkomen van onveiligheid en anderzijds gericht wil blijven op het handhaven van de rechtsorde. In het rapport wordt gesproken over een rol als netwerkpartner én exclusieve handhaver van de rechtsorde. De politiële netwerkfunctie wordt beschreven in termen van 'signaleren en adviseren'. Hiermee wordt blijkens $\mathrm{PiO}$ bedoeld dat de politie aangeeft aan haar ketenpartners waar en op welk moment zij verwacht dat andere partijen een rol spelen in de veiligheidszorg. De rol van de politie in veiligheidsnetwerken is daarmee vooral regisserend en faciliterend: zij moet proberen om andere partijen in de samenleving te mobiliseren en te ondersteunen om hun bijdrage aan een veilige samenleving zo groot mogelijk te maken. Daarnaast moet de politie volgens $\mathrm{PiO}$ proberen om het netwerk te gebruiken om de structurele problemen die ten grondslag liggen aan onveiligheid en criminaliteit op te lossen.

De in 2011 geïnterviewde beleidsmakers stellen meer expliciet dat het netwerken voor de politie nuttig is omdat daardoor oneigenlijk politiewerk kan worden weggeduwd naar ketenpartners. Als voorbeeld wordt een vereenzaamde man genoemd die zeer frequent de politie belt voor allerhande overlast en gevoelens van onveiligheid. In de ogen van geïnterviewde beleidsmakers moet de wijkagent zijn netwerk gebruiken om te zorgen dat de ouderenzorg haar verantwoordelijkheid oppakt en adequate zorg gaat leveren aan de man. Hierdoor raakt de politie het probleem kwijt zodat zij zich kan richten op het 'echte' politiewerk. Bijna alle geïnterviewde beleidsmakers onderkennen dat het netwerken door wijkagenten in de praktijk vaak stroef verloopt. In de ogen van beleidsmakers 'kost' het netwerken de politie veel tijd en levert het vrij weinig op. Politiële netwerkers zouden meer moeten 'nemen' in plaats van 'geven'. De belangrijkste oorzaak die zij hiervoor geven is het gebrek aan inzet van andere actoren in het veiligheidsnetwerk. Het participeren in netwerken wordt volgens de geïnterviewde beleidsmakers te vrijblijvend ingevuld door ketenpartners. Andere actoren in netwerken missen een zekere beslissingsbevoegdheid of hebben volgens de geïnterviewde beleidsmakers simpelweg niet de capaciteiten om de complexe problematiek het hoofd te 
kunnen bieden. Bovendien wordt in de beleving van beleidsmakers de noodzaak bij ketenpartners om problemen op te lossen onvoldoende gevoeld omdat zij niet direct in de frontlijn opereren. Daarom is recentelijk door de Nederlandse politie het instrument programmasturing ingevoerd binnen de Nederlandse politie. Het idee achter programmasturing is dat er tussen de verschillende actoren in het netwerk harde doelen worden gesteld en concrete afspraken worden gemaakt. Het is volgens de geïnterviewde beleidsmakers aan de politieleiding om (in de geïnstitutionaliseerde) netwerken tot dergelijke afspraken te komen en erop toe te zien dat de politiële netwerkfunctie ook conform de concrete afspraken wordt ingevuld en dat er niet meer gedaan wordt door politiële netwerkers dan strikt noodzakelijk is.

Met de komst van de Nationale Politie is de positie van de wijkagent nog verder verstevigd. In het Inrichtingsplan National Politie uit 2012 (p. 38) wordt de wijkagent als centrale speler binnen de politieorganisatie gepositioneerd. In navolging van de in 2011 geïnterviewde beleidsmakers stelt het Inrichtingsplan expliciet dat lokale veiligheidsnetwerken door wijkagenten gebruikt moeten worden om oneigenlijke taken weg te duwen naar anderen in het netwerk: 'Veiligheid is een zaak van alle deelnemers en maatschappelijke processen: burgers, bedrijven en publieke en private organisaties. Ook zij hebben op dit gebied en verantwoordelijkheid en mogen daarop worden aangesproken. De politie is 24/7 in de samenleving aanwezig en signaleert veelal als eerste veiligheidsproblemen. Deze signalen deelt de politie met haar partners, zodat zij hun bijdrage kunnen leveren aan veiligheid.'

\section{De politiële netwerkpraktijk in de gebiedsgebonden politiezorg}

In deze paragraaf beschrijven we de resultaten van ons participatief onderzoek. Eerst gaan we in op de vraag hoe de netwerken binnen de gebiedsgebonden politiezorg eruit zien. Daarna beschrijven we in hoeverre en hoe de gebiedsgebonden politie netwerkt en wat hiervan de opbrengst is voor de kerntaken opsporing en handhaving openbare orde. Vervolgens gaan we in op de contacten die binnen de gebiedsgebonden politiezorg onderhouden worden met individuele burgers en wat deze contacten de politie opleveren voor de kerntaken opsporing en handhaving openbare orde.

\subsection{Hoe zien de netwerken binnen de gebiedsgebonden politiezorg eruit?}

In tabel 3 zijn de bevindingen in één tabel geplaatst. Binnen de onderzochte wijken bestaan de netwerken vooral uit professionele en vrijwillige aanbieders van 'sociale zorg', zoals Bureau Jeugdzorg, aanbieders van geestelijke gezondheidszorg, opbouwwerkers, buurtverenigingen, welzijnswerkers en scholen. De belangrijke twee uitzonderingen zijn: a) woningbouwcoöperaties die een dubbelfunctie hebben als aanbieder van de sociale zorg 'wonen' en een handhavende functie hebben vanwege hun mogelijkheid om personen het huis en daarmee de wijk uit te zetten en; b) de gemeentelijke gebieds-coördinator die een regiefunctie in veel geïnstitutionaliseerde wijkveiligheidsnetwerken vervult. 


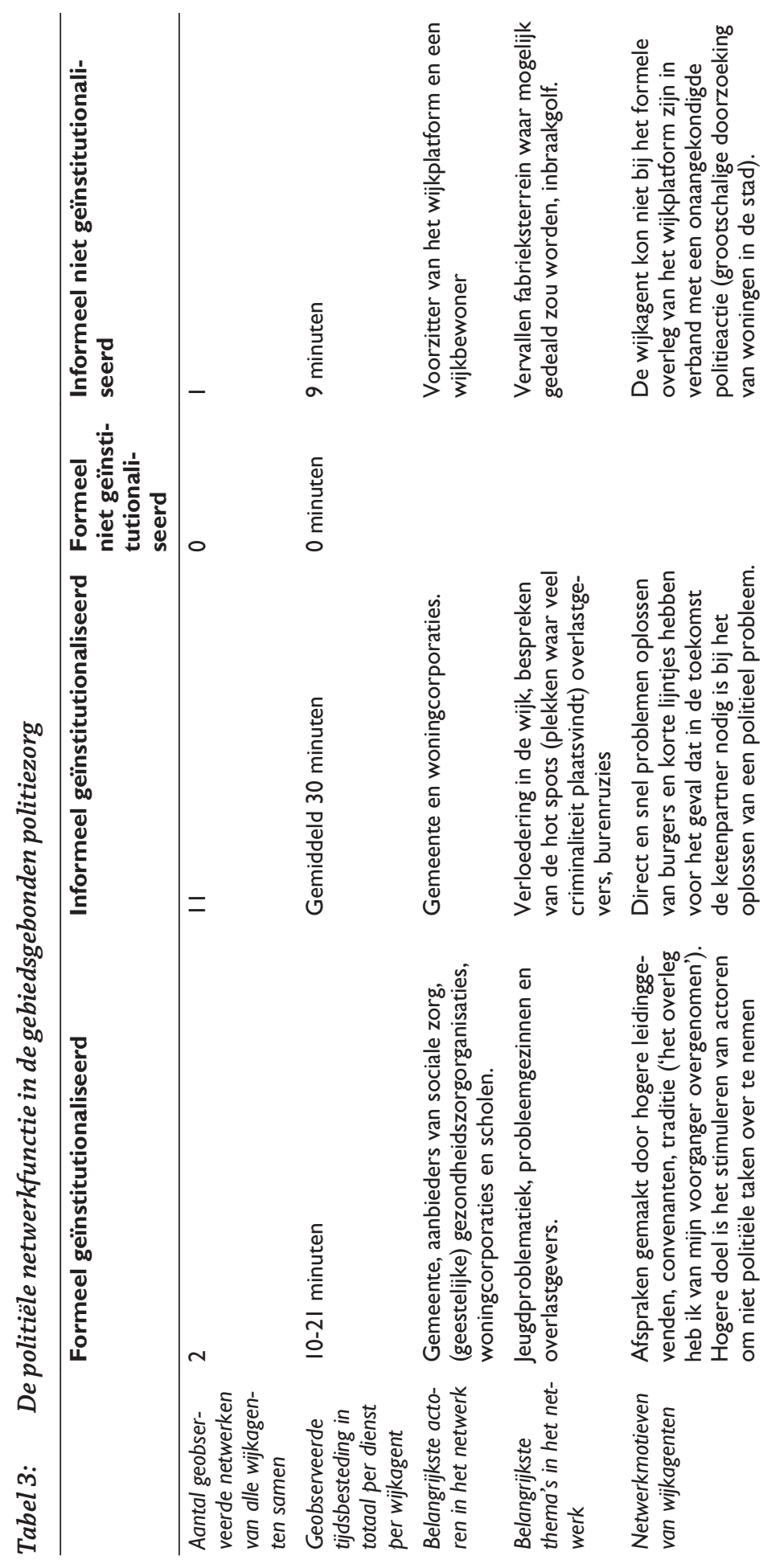




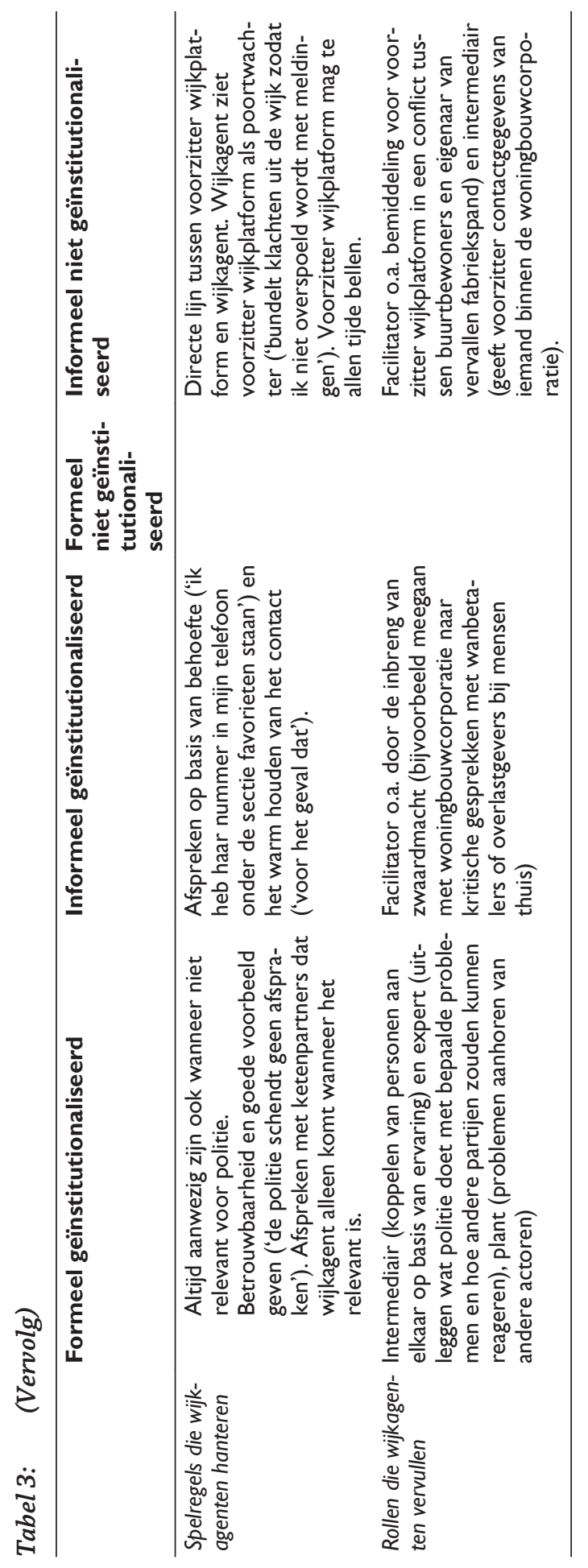




\subsection{In hoeverre en hoe netwerkt de gebiedsgebonden politie?}

In onze observaties van het netwerken door wijkagenten valt op dat de politie weinig tijd besteed aan de netwerkfunctie. Gemiddeld een percentage van $8 \%$ van de totaal geobserveerde diensttijd. Per netwerkfunctie kan dit worden gedifferentieerd waarbij het grootste deel (ongeveer 6\%) wordt besteed aan niet formeel overleg met geïnstitutionaliseerde partijen.

De informele contacten die de wijkagenten met geïnstitutionaliseerde en nietgeïnstitutionaliseerde netwerkpartners onderhouden lijken natuurlijk te verlopen en effectief te zijn waar het gaat om de leefbaarheid van de wijk en neemt het merendeel van de netwerktijd in beslag. Zwaardmacht is dé inbreng van wijkagenten in deze informele veiligheidsnetwerken. Ketenpartners geven aan dat zij het prettig vinden als de wijkagent meegaat wanneer zij bij burgers thuis (moeten) komen. Ketenpartners maken daarnaast naar eigen zeggen graag gebruik van de in hun beleving 'unieke informatiepositie' van de wijkagent, hoewel wij dit niet zo duidelijk hebben kunnen waarnemen. Zowel ketenpartners als wijkagenten vinden het hebben van 'korte lijntjes' met elkaar belangrijk, zodat zij snel in staat zijn om urgente problemen op te lossen.

Wijkagenten tonen zich bewust dat ze niet iedere keer 'de aap op de schouder moeten nemen' (een uitdrukking die wijkagenten veelvuldig gebruiken om aan te geven dat ze niet voor ieder probleem in de wijk verantwoordelijk zijn en dat ook andere ketenpartners een taak hebben), toch onderkennen ze allemaal impliciet en expliciet dat ze (ook) moeten 'geven' aan het netwerk om in andere gevallen te kunnen 'nemen' van het netwerk, ook wanneer dit 'geven' geen verband houdt met de (kern)taken van de politie en daarmee in strijd is met het staande landelijke en regionale politiebeleid. Dit hebben wij zo ook waargenomen tijdens de netwerkoverleggen waaraan de wijkagenten deelnamen. Opgemerkt moet hierbij worden dat in de gesprekken met de wijkagenten bij wijkagenten zelf veel onduidelijkheid leeft over wat nu wel en niet precies onder de kerntaken valt. In de praktijk zijn ze niet zozeer bezig met het tot uitvoering brengen van de politiële kerntaken, maar vooral met het oplossen van lokale veiligheidsproblemen die zij als individu als belangwekkend en problematisch beschouwen. Dit verklaart dan ook dat er per geobserveerde wijkagent verschillen zijn aan te wijzen in de wijze waarop in netwerken geopereerd wordt. De ene wijkagent besteedt bijvoorbeeld meer tijd aan het onderhouden van contacten met welzijnsorganisaties, omdat hij persoonlijk begaan is met een aantal problematische alleenstaanden in zijn wijk. Daarentegen is een andere wijkagent meer actief in het burgerplatform om wijkbewoners te mobiliseren om hun inbraakpreventie te verbeteren. Ook ervaringen uit het verleden spelen een rol. Een netwerkpartner die in het verleden afspraken niet is nagekomen wordt in sommige gevallen niet meer als volwaardige partij in het netwerk beschouwd. Een wijkagent gaf bijvoorbeeld aan niets te willen doen voor vertegenwoordiger $\mathrm{X}$ van netwerkpartner $\mathrm{Y}$, omdat hij zich simpelweg door $\mathrm{X}$ niet serieus genomen voelde.

In de perceptie van de geobserveerde wijkagenten werkt formalisering van de samenwerking averechts. Dit laat onverlet dat een geobserveerde wijkagent bij- 
voorbeeld wel een deel van zijn werktijd op het gemeentehuis is gaan zitten om toegankelijker te zijn voor netwerkpartners op het gemeentehuis. Volgens deze wijkagent is dit echter geen formele vorm van samenwerken, maar bevordert dit juist de korte lijntjes. Door in deze netwerken te benoemen wat de politie doet en het goede voorbeeldgedrag te vertonen (bijvoorbeeld alle vergaderingen bijwonen, ook wanneer deze niet relevant zijn voor de politie) hopen enkele wijkagenten andere partijen te stimuleren om niet-politiële taken over te nemen of in ieder geval de eigen verantwoordelijkheid adequaat in te vullen. Ook dit is weer een voorbeeld van het 'geven' en 'nemen'-principe dat wijkagenten hanteren. Andere wijkagenten zijn meer pragmatisch en bespreken met de voorzitter van het overleg dat zij alleen aanwezig zijn wanneer het relevant is voor de politie. Uitgangspunt bij iedere geobserveerde wijkagent lijkt te zijn dat 'de politie geen afspraken schendt'.

In de door ons geanalyseerde netwerken heeft de politie geen regierol. De rollen die wij wel waargenomen hebben zijn plant (formeel overleg), initiator, expert en intermediair (formeel en informele overleggen) en facilitator (informele overleggen).

\subsection{Opbrengst van het netwerken voor de kerntaken opsporing en handhaving openbare orde}

Tijdens onze observaties hebben wij niet waargenomen dat het netwerken door de wijkagenten geleid heeft tot enige vorm van aantoonbare opbrengst voor de opsporing of de handhaving van de openbare orde. Ook de wijkagenten zelf konden geen voorbeelden van een dergelijke opbrengst geven.

Toch oordelen wijkagenten positief over het informele netwerken met ketenpartners en de opbrengst die deze vorm van netwerken heeft voor hun eigen werk, hoewel zij vaak niet gemakkelijk onder woorden kunnen brengen wat deze exacte opbrengst van het netwerken precies geweest is. Wijkagenten zien als opbrengst van deze netwerken dat ze korte lijntjes hebben met de ketenpartners, dat ze op de hoogte zijn van elkaars activiteiten en dat 'kleine' problemen snel kunnen worden opgelost. De concrete opbrengst die we ze wel kunnen geven heeft vooral betrekking op het bestrijden van sociale overlast en het vergroten van de leefbaarheid in de wijk. Het gaat dan bijvoorbeeld om het samenwerken met een woningbouwcorporatie om een overlastgevende huurder uit huis te plaatsen - de wijkagent levert een sfeerrapportage aan op basis waarvan uithuisplaatsing door woningbouwcorporatie kan plaatsvinden). Of ze gaan samen met een vertegenwoordiger van de woningbouwcorporatie langs bij een huurder om deze aan te spreken over de overlast die hij veroorzaakt. Zwaardmacht is dan het natuurlijke middel dat wijkagenten (soms onbewust) inzetten. Een ander voorbeeld is een wijkagent die via zijn netwerk bij de gemeente verkeersborden gaat regelen rond een school. Hij doet dit na klachten van de school en specifiek klaar-overs over het slechte zicht rond de oversteekplaats veroorzaakt door de geparkeerde auto's langs de weg. Dit probleem zorgde volgens de school en de klaar-overs soms voor 
gevaarlijke situaties, alhoewel dit volgens de wijkagent niet was terug te zien in de statistieken.

\subsection{Eén-op-een contacten met burgers}

Wijkagenten besteedden tijdens onze observaties tussen de 35 tot 60 minuten per dienst aan het opbouwen en onderhouden van relaties met burgers. In de meeste gevallen ging het om het aangaan en onderhouden van contacten met individuele burgers waarvan de wijkagent denkt of uit het verleden weet dat ze voor hem relevant zijn of dit mogelijk worden. Het kan hierbij gaan om het onderhouden van contacten met informanten in de wijk, het op 'gesprek' gaan bij (ex-)verslaafden, handelaren in verdovende middelen of pedofielen (om ze 'uit de anonimiteit te halen'), het opbouwen en onderhouden van een band met een jeugdhanggroep of psychiatrische patiënten. De wijkagenten stellen dat zij de meeste relevante bewoners in hun wijk kennen en in de regel ook herkend worden als zijnde de wijkagent. Dit heeft volgens de meeste wijkagenten wel ten minste een jaar gekost.

De geobserveerde wijkagenten beschouwen het burgercontact naar eigen zeggen als een van de kernaspecten van hun werk. Wijkagenten vinden het gerechtvaardigd om hier veel tijd in te investeren (in tegenstelling tot het netwerken waarmee veel tijdbewuster wordt omgegaan). Deze tijd gebruikten ze tijdens onze observaties met name voor het voeren van face-to-face-gesprekken. De motieven van wijkagenten om contacten aan te gaan en te onderhouden met mensen uit de wijk zijn in de eerste plaats instrumenteel van aard. Uit de observaties blijkt dat wijkagenten veel contacten aangaan en onderhouden met burgers vanuit de gedachte dat zij wellicht politie-relevante informatie (kunnen) krijgen en/of een zekere 'welwillendheid' bij personen of groepen opbouwen. In de tweede plaats onderhouden wijkagenten contacten met buurtbewoners omdat ze willen laten zien dat ze zich betrokken voelen bij de problemen van burgers en in sommige gevallen ook een zekere verantwoordelijkheid voelen om deze problemen te helpen doen oplossen.

Naast de contacten die wijkagenten zelf aangaan, hebben wij ook geobserveerd dat ze bij de keuze om contact op te nemen met burgers gestuurd worden door de collega's van de noodhulp en netwerkpartners. Zo kregen meerdere wijkagenten tijdens onze observaties e-mails met daarin verzoeken om bij bepaalde mensen langs te gaan, bijvoorbeeld omdat ze een warrige indruk maakten of omdat ze zichzelf aan het verwaarlozen waren. Wijkagenten worden vanzelfsprekend ook direct door burgers benaderd met vragen of meldingen van overlast. Hoewel veel meldingen die wijkagenten krijgen niet direct iets met het primaire politiewerk te maken hebben, besluiten wijkagenten vaak toch om poolshoogte te nemen. Wijkagenten vinden het in de regel moeilijk om aan te geven wat de relatie is van dit werk met het politiewerk, maar stellen desgevraagd dat ze vinden dat ze tot op zekere hoogte een bepaalde verantwoordelijkheid hebben voor het welzijn van de bewoners in hun wijk. De ene wijkagent gaat hierin verder dan de andere. 
De wijkagenten blijken zich tijdens de geobserveerde diensten zeer bewust van het belang van goede burgercontacten. Bij het onderhouden van relaties met burgers passen zij dan ook (veelal impliciet) het principe van 'geven en nemen' toe. Ze proberen met andere woorden te investeren in de relaties met burgers, omdat ze hopen dat ze er op een ander moment weer iets voor terugkrijgen (in de vorm van relevante informatie of steun bij het oplossen van problemen). Zo passen sommige wijkagenten bij het 'innen' van boetes een flexibel betalingsbeleid toe om goodwill te kweken bij lastige burgers of helpt een wijkagent een coffeeshophouder met de aanvraag van een vergunning van de gemeente eveneens om goodwill te creëren. Tijdens de observaties hebben we verschillende rollen waargenomen die wijkagenten vervullen bij het aangaan en onderhouden van contacten met burgers: expertrol (burgers die tijdens een nazorggesprek na een inbraak vragen stellen aan de wijkagent over het hang- en sluitwerk); faciliterende rol (een wijkagent die een bewoonster uit zijn wijk helpt bij het krijgen van een nieuwe voordeur); een intermediërende rol (een wijkagent die een vrouw doorverwijst naar het servicenummer van de gemeente om daar haar overlast m.b.t. hondenpoep te melden) en tot slot de rol van plant (een wijkagent die het verhaal aanhoort van een boze burger maar er vervolgens niets mee doet).

\subsection{Opbrengst van het een-op-een contact met burgers voor de kerntaken opsporing en handhaving openbare orde}

Tijdens de geobserveerde diensten hebben wij twee directe voorbeelden waargenomen van opbrengst van het opbouwen en onderhouden van contacten met burgers in de wijk die direct gerelateerd is aan een primair politieproces, namelijk opsporing. Tijdens een van de geobserveerde diensten krijgt een wijkagent informatie van een individuele bewoner uit de wijk over het feit dat de buurman van de bewoner benaderd is om hennepknoppen te knippen bij een man uit de wijk. $\mathrm{Na}$ een check in de computersystemen blijkt dat de informatie wel eens heel betrouwbaar zou kunnen zijn, omdat diegene die toenadering heeft gezocht in het verleden al eerder betrokken is geweest bij de productie en handel van hennep. De wijkagent geeft deze informatie door aan zijn collega's van de afdeling opsporing, zodat er enkele weken later een inval kan plaatsvinden en er daadwerkelijk een hennepplantage kan worden opgerold. In het tweede voorbeeld krijgt een wijkagent tijdens zijn dienst te horen dat er een gewelddadige winkeloverval is gepleegd. Op basis van het signalement en de vermoedelijke naam van de dader over de portofoon kan de wijkagent gerichte informatie geven aan zijn collega's van de opsporing over waar de persoon zich vermoedelijk bevindt. Hij kent ook de vriendin van de vermoedelijke dader goed en besluit langs haar adres te rijden om te kijken of de auto van de vermoedelijke dader voor de deur staat. Dit is inderdaad het geval, zodat de man dezelfde avond door een politieteam nog kan worden aangehouden. Naast deze voorbeelden die wij zelf direct hebben kunnen waarnemen, konden wijkagenten nog veel meer voorbeelden geven van gevallen waarin de kennis over en informatie van een-op-eenburgercontacten geleid heeft tot concrete opbrengst voor de kerntaken opsporing en handhaving openbare orde. 


\section{Discussie}

Het overall beeld van ons participatief onderzoek is dat daar waar het politiebeleid duidelijk is ('netwerken is er om informatie te halen en oneigenlijke taken weg te zetten') er in de praktijk van de gebiedsgebonden politiezorg geen operationalisatie van dit beleid lijkt te bestaan. In de dagelijkse praktijk van de wijkagent is zichtbaar dat deze gedreven functionarissen tegen het formele beleid in zich als 'echte' netwerkers conform de netwerktheorie opstellen om vooral 'sociale overlast' in de buurt effectief te kunnen bestrijden en de leefbaarheid te vergroten. In onze observaties en interviews hebben wij geen aantoonbare betekenis van het netwerken van de wijkagent voor de kerntaken opsporing en handhaving openbare orde waargenomen. Geen misverstand: de individuele relaties tussen wijkagenten en burgers dragen hier volgens onze observaties wel toe bij.

Deze bevindingen laten onverlet dat we in onze observaties wel een belangrijke betekenis zien van het (informele) netwerken door de wijkagent voor de hulpverlening aan individuen en de leefbaarheid in de wijk. Dit heeft ogenschijnlijk gevolgen voor (het gevoel van) sociale veiligheid en daarmee lijkt het netwerken wel een positieve betekenis te hebben voor de politiefunctie in de samenleving. Of het hiervoor noodzakelijk is dat de politie deelneemt aan allerhande (formeel georganiseerde) geïnstitutionaliseerde netwerken kunnen wij op basis van ons onderzoek bevestigen noch ontkrachten.

Dat het participeren in veiligheidsnetwerken ogenschijnlijk leidt tot een verhoging van de sociale veiligheid en leefbaarheid in wijken, komt overeen met de eerdere conclusie die onder andere Johnston \& Shearing (2003) en Wood \& Shearing (2007) trokken. Onze bevindingen lijken daarentegen op onderdelen te contrasteren met de bevindingen van Terpstra (2010; 2008a; 2008b) die op basis van participatief onderzoek tot de conclusie komt dat wijkagenten in de praktijk vaak deelnemen aan netwerken en samenwerkingsverbanden rond de aanpak van uiteenlopende problemen in hun werkgebied. Terpstra kwantificeert in zijn onderzoek echter niet wat hij met 'vaak' bedoeld. Op basis van onze observaties menen wij dat de hoeveelheid tijd die wijkagenten aan het participeren in netwerken besteden beperkt is. Een mogelijke verklaring voor het gevonden verschil is dat de netwerkfunctie binnen het korps waarin wij onderzoek deden is opgesplitst tussen de wijkagent en een zogeheten netwerkinspecteur. Deze netwerkinspecteur neemt volgens de geobserveerde wijkagenten vanuit de politie deel aan enkele formeel georganiseerde, geïnstitutionaliseerde netwerken rond verschillende (sociale!) veiligheid- en leefbaarheidsvraagstukken. Een andere verklaring zou kunnen zijn dat de politiekorpsen waarbinnen Terpstra (2010; 2008a; 2008b) onderzoek heeft verricht een andere invulling geven aan het landelijke politiebeleid met betrekking tot de politiële netwerkfunctie en een actievere rol vervullen in lokale veiligheidsnetwerken. Bedacht moet immers worden dat ons observaties plaatsvonden binnen een politiekorps en daarmee niet zondermeer veralgemeniseerd kunnen worden naar andere Nederlandse politiekorpsen. 
Een van de lessen die wij getrokken hebben is dat het voor de verdere ontwikkeling van het onderzoek naar de politiële netwerkfunctie noodzakelijk is dat onderzoekers transparanter rapporteren over hun bevindingen en de conclusies die ze daaruit trekken. Alleen dan wordt het mogelijk om resultaten te kunnen vergelijken en factoren te kunnen identificeren die invloed hebben op de effectiviteit van de netwerkfunctie. Zoals hierboven al opgemerkt, is het nu moeilijk om de bevindingen tussen onze bevindingen en die van Terpstra (2008b) te vergelijken, omdat Terpstra zijn bevindingen hoofdzakelijk kwalitatief heeft beschreven. Wij hebben geprobeerd om de transparantie te vergroten door zo concreet mogelijk te beschrijven in hoeveel netwerken de wijkagenten participeerden en de hoeveelheid tijd die ze daaraan besteden. Bovendien hebben wij onze observatieverslagen gepubliceerd op het internet om een secundaire analyse van onze bevindingen mogelijk te maken.

Een tweede verschil met het onderzoek van Terpstra (2010; 2008a; 2008b) is dat wij geen initiërende, coördinerende of regisserende rol van de wijkagenten hebben waargenomen tijdens onze observaties. Waar Terpstra (2008b) constateert dat '...wijkagenten in de praktijk vaak toch weer gedwongen voelen de regie over andere partijen in de veiligheidszorg op zich te nemen en deze te sturen', concluderen wij op basis van onze observaties en interviews dat de gemeente in de verschillende geobserveerde lokale veiligheidsnetwerken een serieuze en belangrijke rol speelt in zowel formele als informele netwerkverbanden. Dat het in de perceptie van sommige geobserveerde wijkagenten altijd beter kan (de trage besluitvorming binnen gemeenten wordt door alle geobserveerde wijkagenten als een belemmering ervaren) neemt niet weg dat een regierol wel degelijk wordt ingevuld. Dat wij geen coördinerende of regisserende rol van wijkagenten hebben waargenomen, betekent wederom niet dat deze niet worden vervuld in het korps waarbinnen wij onderzoek hebben verricht of daarbuiten. Volgens ons laat het vooral zien dat de perceptie van de wijkagenten dat zij een leidende positie innemen in lokale veiligheidsnetwerken niet altijd (meer) overeenkomt met de realiteit. Misschien was deze perceptie enkele jaren geleden nog gerechtvaardigd; anno nu lijkt het erop dat de inbreng van andere actoren in het lokale veiligheidsnetwerk vergroot is.

Ons participatieve onderzoek kent enkele beperkingen. Ten eerste moet opgemerkt worden dat onze aanwezigheid de keuze van de werkzaamheden en de tijd die hieraan besteed is mogelijk heeft beïnvloedt. Hoewel we nadrukkelijk na afloop van ons onderzoek de wijkagenten hierop bevraagd hebben, en zij aangegeven hebben dat zij zich net zo gedragen hebben als ze altijd doen, valt het niet uit te sluiten dat er toch sprake is geweest van enige beïnvloeding. Ten tweede bleek het tijdens de observaties praktisch niet werkbaar om alle telefoongesprekken en het e-mailverkeer met ketenpartners bij te houden. Daarom hebben wij na iedere geobserveerde dienst een inschatting moeten maken van de tijd die wijkagenten aan deze activiteiten besteed hebben. Alhoewel het maar om een beperkte hoeveelheid tijd ging in onze inschatting, bevelen wij aan om in toekomstig onderzoek hier nadrukkelijker op te letten en de wijkagent te vragen om ook zelf bij te houden hoeveel tijd hij aan deze activiteiten besteed. Ten derde is een andere 
beperking van ons onderzoek dat we de opbrengst van de politiële netwerkfunctie voor de kerntaken opsporing en handhaving openbare orde alleen beoordeeld hebben gedurende de weken dat de observaties plaatsvonden. Het zou mogelijk kunnen zijn dat sommige opbrengst van de politiële netwerkfunctie zich pas later manifesteren. Echter denken wij zelf dat hiervan geen sprake is, omdat wijkagenten ons tijdens het participatieve onderzoek nauwelijks voorbeelden konden geven van situaties waarin de politiële netwerkfunctie een aantoonbare bijdrage had geleverd aan de kerntaken opsporing en handhaving openbare orde. Ten vierde en tot slot moet nogmaals benadrukt worden dat ons onderzoek heeft plaatsgevonden binnen één politiekorps in Nederland. Hoewel er op landelijk niveau beleid ontwikkeld is dat aangeeft wat het primaire doel zou moeten zijn van de politiële netwerkfunctie, is er geen landelijk beleid dat aangeeft hoe de netwerkfunctie in de praktijk vorm en inhoud moet krijgen. De politiële netwerkfunctie kan dus regionaal naar eigen inzicht worden uitgevoerd. Uit ons onderzoek blijkt zelfs dat binnen één korps al op verschillende wijze invulling wordt gegeven aan de netwerkfunctie. Nader onderzoek zowel binnen als buiten Nederland bevelen wij dan ook aan om de bevindingen in ons onderzoek te valideren.

Naast de algemene opmerking dat meer empirisch onderzoek naar de politiële netwerkfunctie binnen de gebiedsgebonden politiezorg wenselijk is, willen we nog drie meer specifieke aanbevelingen voor vervolgonderzoek geven. Ten eerste bevelen we meer vergelijkend onderzoek aan waarin het functioneren en de opbrengsten van lokale netwerken binnen verschillende regionale eenheden met elkaar wordt vergeleken. In hoeverre verschillen regionale eenheden qua participatie in informele/formele netwerken en een-op-een burgercontacten? En hoeverre verschillen de opbrengsten in lokale netwerken tussen verschillende regionale eenheden? Waardoor kunnen die verschillen worden verklaard? En in hoeverre leidt meer een-op-een contact ook tot meer opbrengsten voor de kerntaken opsporing en handhaving openbare orde. Ten tweede zou onderzocht kunnen worden in welke mate de netwerkactiviteiten en een-op-een activiteiten bijdragen aan het vertrouwen van burgers en organisaties in de politie. Dit is namelijk mogelijk een andere 'opbrengst' van de politiële netwerkfunctie binnen de gebiedsgebonden politiezorg die we in ons onderzoek niet expliciet hebben onderzocht. Ten derde is onderzoek wenselijk naar de vraag of de politiële netwerkfunctie van de wijkagent bijdraagt aan criminaliteitspreventie.

\section{Tot slot}

Wij concluderen dat de gebiedsgebonden politie (inderdaad) geconfronteerd wordt met, in de perceptie van wijkagenten (maar ook leidinggevenden en netwerkpartners), actieve veiligheidsnetwerken. De netwerktheorie laat zien dat het effectief kunnen vervullen van een netwerkfunctie 'geven en nemen' betekent: politie die een rol ambieert in die veiligheidsnetwerken zal zich moeten openstellen voor en committeren aan de prioriteiten die vanuit de netwerken komen waaraan de politie deelneemt. Het huidige politiebeleid, dat vooral wil nemen uit 
en niet wil geven aan (relevante) veiligheidsnetwerken, betekent echter feitelijk al op voorhand dat de politie geen volwaardige rol in de netwerken zou kunnen spelen. Wij menen dat nader onderzoek wenselijk is naar onze hypothese dat wijkveiligheid gebaat is bij (meer) goede wijkagenten met een brede functie-invulling en een hoge mate van autonomie bij het bepalen van de mate waarin en wijze waarop het netwerken plaatsvindt. De illusie bij beleidsmakers dat het netwerken moet leiden tot het kunnen wegzetten van niet-primair geachte politietaken moet hierbij dus worden losgelaten. Daarmee concluderen wij overall dat in de kerntakendiscussie van de politie een realistische beschouwing over de netwerkfunctie van de politie niet mag ontbreken. Anders geformuleerd: een politieorganisatie die zich meer wil toeleggen op de kerntaken opsporing en handhaving openbare orde, ontkomt er niet aan om de politiële aanwezigheid in lokale veiligheidsnetwerken te beperken. Meer nadruk op de kerntaken zal echter ook betekenen dat de bijdrage van de politie aan het bestrijden van sociale overlast en het verhogen van de leefbaarheid in buurten minder zal worden. Wat hiervan de mogelijke gevolgen zijn voor de legitimiteit van de politie en de wijkveiligheid, zal dan nader onderzocht moeten worden.

\section{Literatuur}

Agranoff, R. \& M. McGuire, 'Managing in network settings', Review of Policy Research, 1999/1, p. 18-41.

Bruijn, H. de \& E. ten Heuvelhof, Management in networks. On multi-actor decision making, Londen: 2008.

Castells, M., 'A network theory of power', International Journal of Communication, 2011/5, p. 773-787.

Crawford, A., The local governance of crime. Appeals to partnerships and community, Oxford: 1997.

Crawford, A. (ed.), Plural policing. The mixed economy of visible patrols in England and Wales, Bristol: 2005.

Dupont, B., 'Security in the age of networks', Policing and Society, 2004/1, p. 76-91.

Edwards, A. \& G. Hughes, 'Introduction. The new community governance of crime control', G. Hughes \& A. Edwards (eds.), Crime control and community. The new politics of public safety, Cullompton: 2002.

Fleming, J. \& J. Wood (eds.), Fighting crime together. The challenges of policing and security networks, Sydney: 2006.

Hajer, M.A. \& H. Wagenaar (eds.), Deliberative policy analysis. Understanding governance in the network society, Cambridge: 2003.

Hamilton-Smith, N., S. Mackenzie, A. Henry \& C. Davidones, 'Community policing and reassurance. Three studies, one narrative', Criminology and Criminal Justice, 2013 (published online before print).

Hughes, G. \& M. Rowe, 'Neighbourhood policing and community safety. Researching the instabilities of the local governance of crime, disorder and security in contemporary UK', Criminology and Criminal Justice, 2007/4, p. 317-346.

Johnston, L., 'From 'community' to 'neighbourhood policing'. Police community support officers and the 'police extended family' in London', Journal of community \& applied social psychology, 2005/3, p. 241-254. 
Johnston, L. \& C. Shearing, Governing security. Explorations in Policing and Justice, Londen: 2003.

Jones, M., 'Governance, integrity, and the police organization', Policing. An International Journal of Police Strategies \& Management, 2002/2, p. 338-350.

Jones, T. \& T. Newburn, 'The transformation of policing? Understanding current trends in policing systems', British Journal of Criminology, 2002/1, p. 129-146.

Kickert, W J., E.H. Klijn \& J.F.M. Koppenjan (eds.), Managing complex networks. Strategies for the public sector, Englewood Cliffs NJ: 1997.

Loader, I. \& N. Walker, 'Policing as a public good. Reconstituting the connections between policing and the state', Theoretical Criminology, 2001/1, p. 9-35.

Nationale Politie, Inrichtingsplan Nationale Politie, 2012 (versie 3).

Politie in Ontwikkeling PiO (2005). Gedownload op 26 september 2014 van: http://vpm. politieacademie.nl/Docs/Politie\%20in\%20ontwikkeling.pdf

Provan, K.G., A. Fish \& J. Sydow, 'Interorganizational networks at the network level. A review of the empirical literature on whole networks', Journal of management, 2007/3, p. 479-516.

Rhodes, R.A., 'Understanding governance. Ten years on.' Organization studies, 2007.8, p. 1243-1264.

Shearing, C., 'Nodal security', Police Quarterly, 2005/1, p. 57-63.

Steden, R. van (ed.), Strategieën van lokale veiligheid. Een achtergrondstudie en drie reflecties, Amsterdam: 2011.

Terpstra, J., 'Police, local government, and citizens as participants in local security networks', Police Practice and Research. An International Journal, 2008/3, p. 213-225, 2008a.

Terpstra, J., Wijkagenten en hun dagelijks werk. Een onderzoek naar de uitvoering van gebiedsgebonden politiewerk, Den Haag/Apeldoorn: 2008b.

Terpstra, J., 'Community policing in practice. Ambitions and realization', Policing, 2010/1, p. 64-72.

Terpstra, J. \& R. Kouwenhoven, Samenwerking en netwerken in de veiligheidszorg, Zeist: 2004 (serie Politie \& Wetenschap).

Thomson, A.M. \& J.L. Perry, 'Collaboration processes. Inside the black box', Public Administration Review, 2006/1, p. 20-32.

Van Maanen, J., 'The fact of fiction in organizational ethnography', Administrative Science Quarterly, 1979/4, p. 539-550.

Wood, J. \& C. Shearing, Imagining security, New York: 2007. 